$$
\begin{aligned}
& 1,75 \\
& +8
\end{aligned}
$$

Submarine Canyon Deposits, Central California Coast, and Their Possible Relation to an Eocene Low Sea-Level Stand U.S. GEOLOGICAL SURVEY BULLETIN 1539 



\section{Submarine Canyon Deposits,}

Central California Coast, and Their Possible Relation to an Eocene Low Sea-Level Stand

By VICTOR M. SEIDERS and JAMES M. JOYCE

U.S. GEOLOGICAL SURVEY BULLETIN 1539

Local and regional stratigraphic relations with new fossil determinations

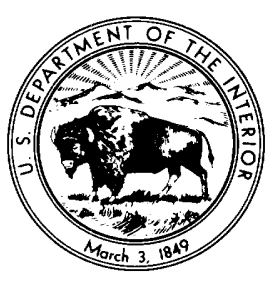

UNITED STATES GOVERNMENT PRINTING OFFICE. WASHINGTON : 1984 


\section{DEPARTMENT OF THE INTERIOR}

WILLIAM P. CLARK, Secretary

\section{U. S. GEOLOGICAL SURVEY}

Dallas L. Peck, Director

\section{Library of Congress Cataloging in Publication Data}

Seiders, Victor M., 1931-

Submarine canyon deposits, central California coast, and their possible relation to an Eocene low sea-level stand.

(U.S. Geological Survey Bulletin 1539)

Bibliography: p. 14-16

Supt. of Docs. no.: I 19.3:1539

1. Marine sediments-California. 2. Submarine valleys. 3. Sea levelCalifornia. 4. Geology, stratigraphic-Eocene. I. Joyce, James M. II. Title. III. Series: United States. Geological Survey. Bulletin 1539.
QE75.B9 no. 1539
$557.3 \mathrm{~s}$
[GC398]
[551.4'42]
$84-600082$

For sale by the Distribution Branch, U.S. Geological Survey, 604 South Pickett Street, Alexandria, VA 22304 


\section{CONTENTS}

Page

Abstract _-

Introduction _..... 1

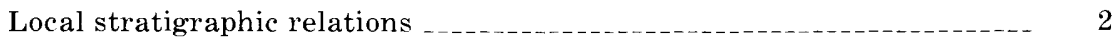

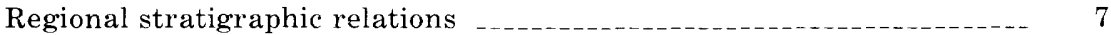

Age significance

References cited _...... 14

\section{ILLUSTRATIONS}

FIGURE 1. Map showing location of area studied and distribution of the Reliz Canyon Formation

2. Photograph showing buttress unconformity exposure in cliff north of Escondido campground

3. Geologic map of study area north of Escondido campground

4. Cross section showing relations between Ruetz's measured section and the cliff exposure of buttress unconformity

5. Stereoscopic pair of aerial photographs showing the area near the buttress unconformity exposure

6. Photographs of outcrops of the Reliz Canyon Formation

7. Paleogeographic block diagram showing inferred relation of submarine canyon deposits near Escondido campground to deposits near The Indians Ranger Station

\section{TABLE}

TABLE 1. Fossils from Paleocene and Eocene rocks north of Escondido campground 



\title{
SUBMARINE CANYON DEPOSITS, CENTRAL CALIFORNIA COAST, AND THEIR POSSIBLE RELATION TO AN EOCENE LOW SEA-LEVEL STAND
}

\author{
By Victor M. Seiders and James M. Joyce
}

ABSTRACT

A cliff exposure in the northern Santa Lucia Range is interpreted to represent the north margin of an Eocene submarine canyon. The exposure shows an unconformity between The Rocks Sandstone Member of the Reliz Canyon Formation and the underlying crystalline basement rocks. Sandstone beds overlie the unconformity at an angle of about $20^{\circ}$. Stratigraphic relations exposed nearby show that about $220 \mathrm{~m}$ of the Reliz Canyon and Church Creek Formations pinches out northward against the basement across a distance of about $900 \mathrm{~m}$. This corresponds to an original southward slope of the unconformity of about $14^{\circ}$. Farther south, an even steeper slope to the north may be indicated, but a fault of uncertain horizontal displacement intervenes.

The Reliz Canyon Formation seems to have been deposited in a small northwest-trending submarine canyon in the vicinity of the exposed unconformity; elsewhere in the region the Reliz Canyon Formation may have been deposited in two other canyons or restricted basins. Fossil data show that the voluminous sand of The Rocks Sandstone Member was deposited near the earlymiddle Eocene boundary, a postulated time of worldwide low sea level.

\section{INTRODUCTION}

Places where sedimentary rocks lap onto a steeply dipping erosion surface to form a buttress unconformity are rarely well exposed. More often, this relation can only be inferred from careful stratigraphic and structural observations or from seismic profiles (for example, Enos, 1974; Ruetz, 1979). In the course of another study in the Coast Ranges of central California (Seiders and others, 1983a, b), we observed a well-exposed buttress unconformity. Stratigraphic relations nearby indicate that a thick sequence of sandstone pinches out against the unconformity and suggest that the exposures represent the margin of a submarine canyon. The purpose of this report is (1) to describe and illustrate the exposed canyon margin and the sedimentary rocks within the canyon, (2) to describe regional 
geology relating the submarine canyon to other nearby canyons, and (3) to present new data on the age of the deposits, suggesting a correlation with a postulated Eocene low stand of sea level.

We are grateful to Gerta Keller, Kristin A. McDougall, and LouElla Saul for fossil identifications. Keller called our attention to the synchronism of our fossil ages with a postulated worldwide low stand of sea level.

\section{LOCAL STRATIGRAPHIC RELATIONS}

A buttress unconformity is exposed in a cliff in the Los Padres National Forest, northern Santa Lucia Range, about 1.5 $\mathrm{km}$ north of the Escondido campground (figs. 1, 2). Figure 2 is a helicopter view of the cliff showing the unconformity. The trace of the unconformity in the cliff is inclined to the south. The true dip of the unconformity is not precisely determinable. However, at the left edge of figure 2, where the cliff recedes, the apparent dip of the unconformity increases sharply, suggesting that the true dip of the unconformity is to the southwest at this place.

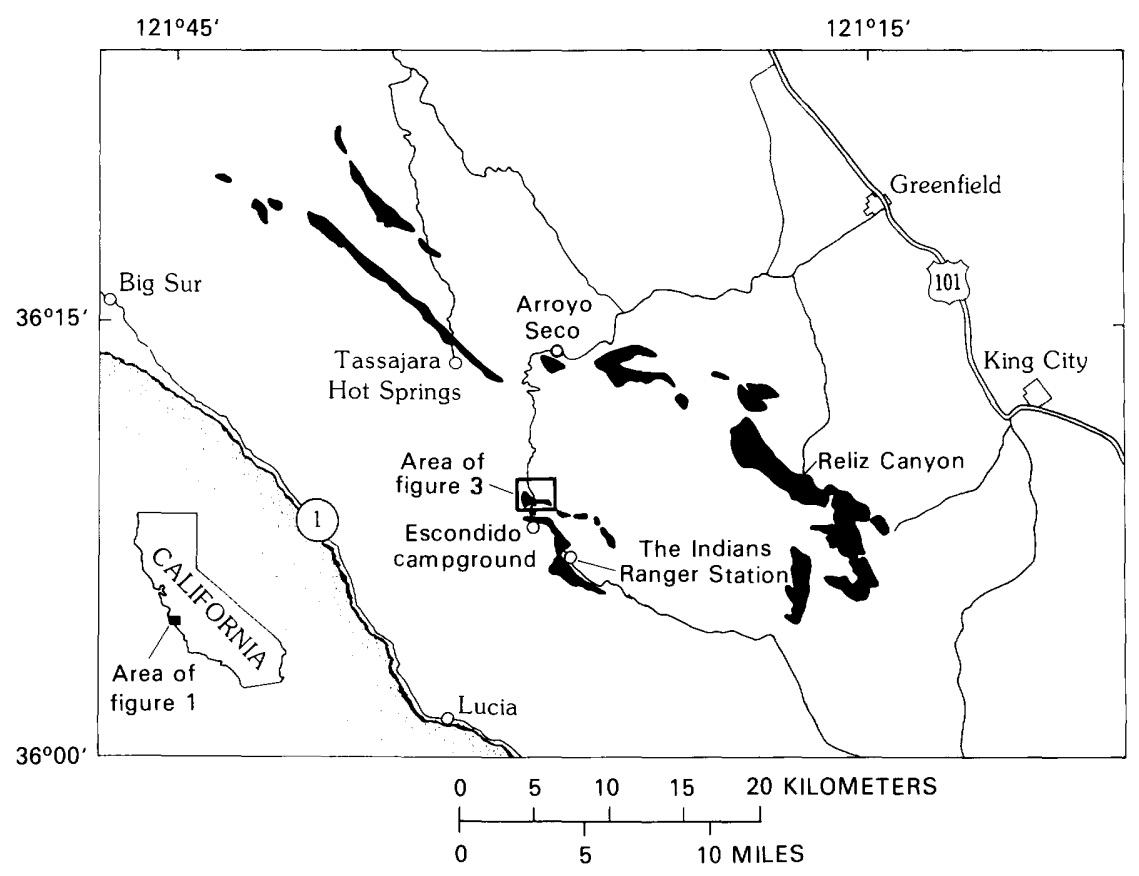

FIGURE 1.-Location of the area studied north of Escondido campground and distribution of the Reliz Canyon Formation (black). 
The rocks below the unconformity are high-grade metasedimentary rocks, including gneiss, marble, and calcsilicate rocks. Well-bedded rocks above and to the right of the unconformity are The Rocks Sandstone Member of the Reliz Canyon Formation. The top of The Rocks Sandstone Member is sharply defined by the prominent ledge at the top of the cliff. The slopes above this ledge are underlain by mudstone of the Church Creek Formation.

Near the unconformity the sandstone beds make an angle of about $20^{\circ}$ with the unconformity surface and thicken away from the unconformity, causing the section to fan out to the south. Thus, the upper beds of sandstone in the right of figure 2 make an angle of about $35^{\circ}$ with the unconformity.

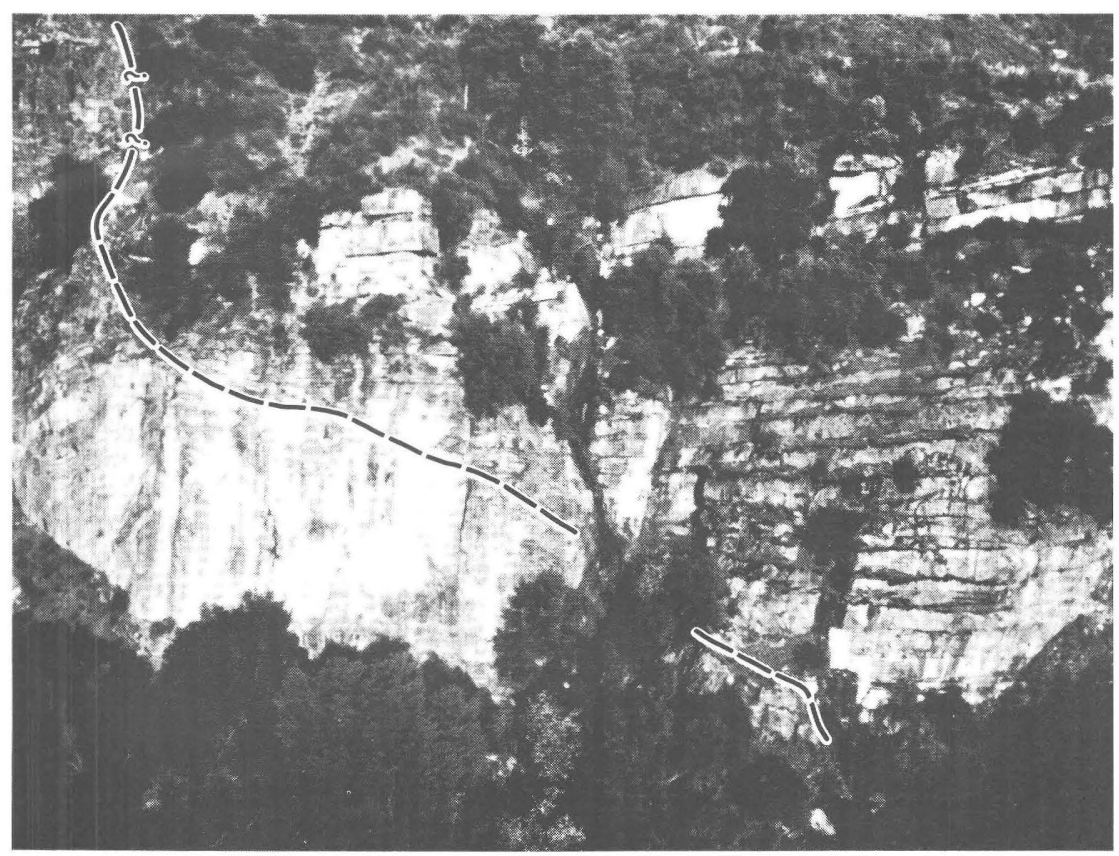

FIGURE 2.-View of the buttress unconformity (dashed line) exposed north of Escondido campground. The view is somewhat oblique to the face of the cliff and, therefore, the scale varies. The photograph encompasses about $150 \mathrm{~m}$ horizontally; height of cliff visible below the top of prominent sandstone face in left center is about $50 \mathrm{~m}$. The cliff trends roughly north-south and view is to the east-northeast. Metasedimentary rocks are present below and to the left of the unconformity. Well-bedded rocks above and to the right of the unconformity belong to The Rocks Sandstone Member of the Reliz Canyon Formation. The brushy area above the sandstone is underlain by the Church Creek Formation. See text for further discussion. 
The contact between the sandstone and the metamorphic rocks is generaly sharp and clean. Locally, a pod of rubble about $1 \mathrm{~m}$ thick intervenes between the basement and the sandstone. The rubble is angular and contains clasts as large as about 20 $\mathrm{cm}$ in diameter. Where the pod lies on a marble lens in the basement, the lower part of the rubble is composed mainly of marble, whereas the upper part contains mainly gneiss clasts. A much more accessible rubble deposit underlies the Church Creek Formation about $150 \mathrm{~m}$ northeast of the cliff exposure.

Figure 3 is a geologic map of the area around the cliff containing the unconformity, and figure 4 is a cross section through part of the area. Strikes and dips of bedding show that the structure near the cliff is synclinal. On the north limb of the syncline the Church Creek Formation rests on basement and dips to the south. Farther north a thin, unnamed unit of Paleocene mudstone lies between the Church Creek and the basement, bounded above and below by unconformities.

The south limb of the syncline is composed of very thick bedded sandstone of The Rocks Sandstone Member which underlies a dip slope inclined to the north (fig. $6 A$ ). Just south of the crest of this slope, near fossil locality 2 (fig. 3), The Rocks Sandstone Member (fig. $6 B$ ) is underlain by the Lucia Mudstone and Junipero Sandstone Members of the Reliz Canyon Formation (we have not shown the members separately on figure 3). The Junipero Sandstone Member rests on basement. Ruetz (1979) measured a section here, and although he used a different stratigraphic terminology, his measurements correspond to $48 \mathrm{~m}$ of the Junipero, $24 \mathrm{~m}$ of the Lucia, and $68 \mathrm{~m}$ of The Rocks. Ruetz's (1979) section does not show the top of The Rocks. We estimate that an additional $60 \mathrm{~m}$ of The Rocks occurs farther north above his measured section. All three members of the Reliz Canyon Formation pinch out between Ruetz's (1979) section and the cliff about $900 \mathrm{~m}$ to the north. About $20 \mathrm{~m}$ of the Church Creek Formation also pinches out against the unconformity, making a total of about $220 \mathrm{~m}$ of section that laps out. Calculated from these data, the overall angle between bedding

FIGURE 3.-Geologic map of the area north of Escondido campground. North is oriented to the left for ease of comparison with stereoscopic pair of aerial photographs (fig. 5). Bottom edge of map is the west edge of Junipera Serra Peak 7-1/2- minute quadrangle. X, fossil locality reported in table 1 . 


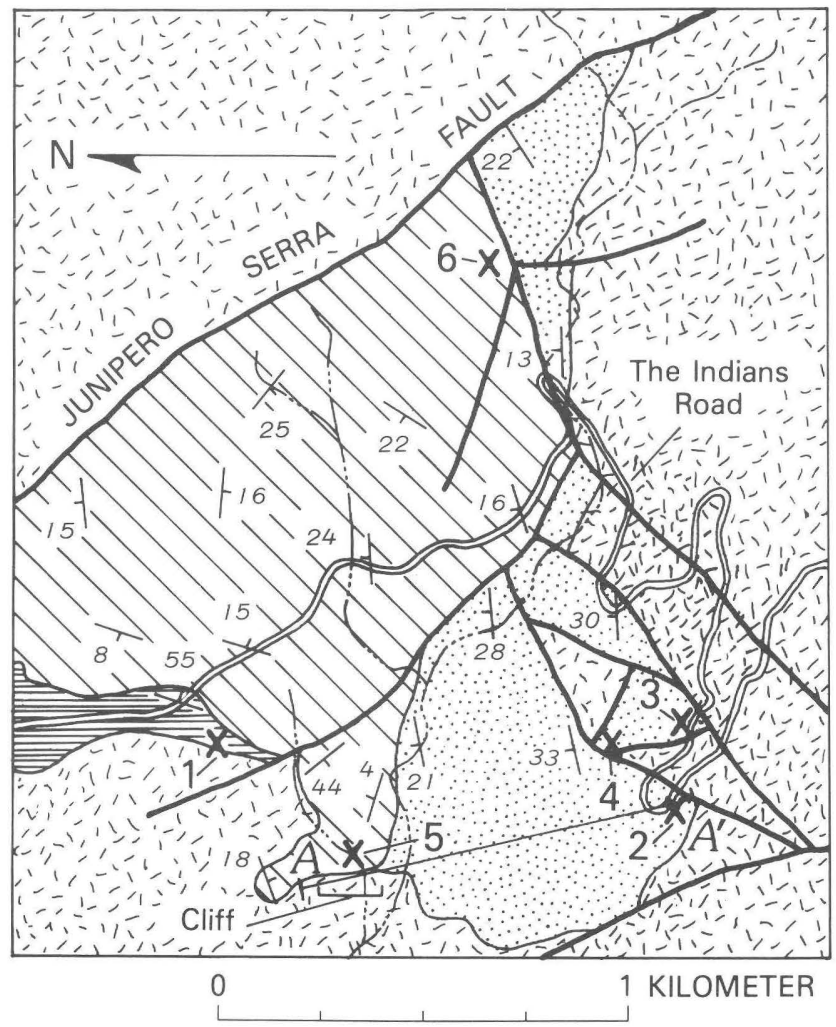

EXPLANATION

TC Church Creek Formation (Eocene)

Tr Reliz Canyon Formation, undivided (Eocene and upper Paleocene)

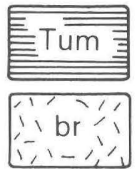

Unnamed mudstone (Paleocene)

Crystalline basement rocks (Cretaceous and older)

Contact

Fault

33
1 Strike and dip of beds 
and the unconformity is $14^{\circ}$, representing the approximate original slope of the unconformity. A half kilometer south of Ruetz's (1979) section, massive sandstones are also absent (see below) and could indicate an even steeper slope (about $23^{\circ}$ ) in that direction. Here, however, a fault of uncertain but probably small horizontal displacement intervenes.

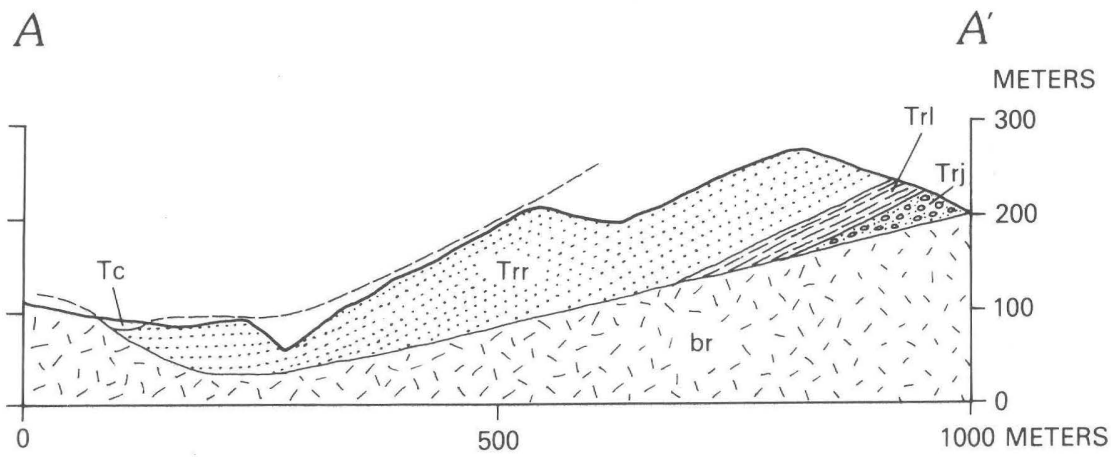

FIGURE 4.-Cross section showing relations between Ruetz's (1979) measured section on right (near fossil locality 2, fig. 3) and the cliff exposure of buttress unconformity on left. br, basement rocks; Trj, Junipero Sandstone Member; Trl, Lucia Mudstone Member; Trr, The Rocks Sandstone Member, Reliz Canyon Formation; Tc, Church Creek Formation.

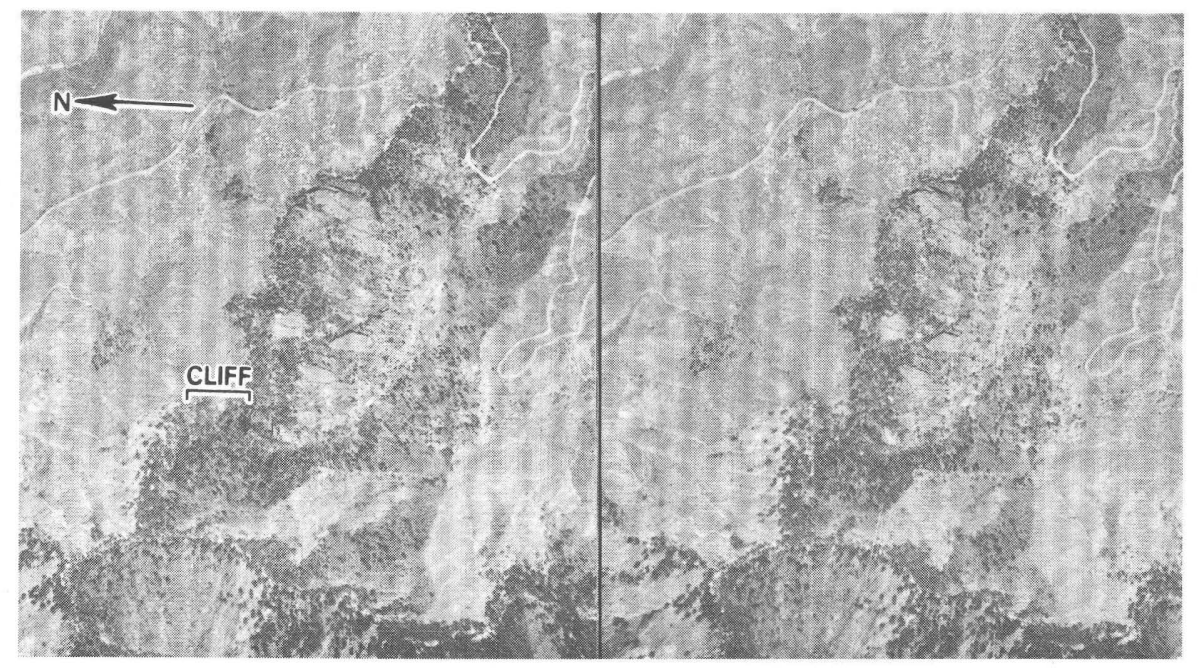

FIGURE 5.-Stereoscopic pair of aerial photographs showing the area near the cliff with the exposed buttress unconformity. Scale is approximately the same as in figure 3. Area of prominent outcrops in right center of photographs corresponds to principal area of outcrop of the Reliz Canyon Formation in the bottom part of figure 3. Large stream at bottom is the Arroyo Seco, outside the area of figure 3. 
Sandstone of the Reliz Canyon Formation north of Escondido campground is generally thick bedded $(1-3 \mathrm{~m})$ and less commonly thin to thick bedded. Many beds are channeled at the base, and bed amalgamation is widespread. Graded bedding is poorly developed and is generally seen only in the uppermost parts of beds. Local unconformities with inclined and truncated beds occur within the section. Mudstone rip-up clasts are common. The sandstone is generally coarse grained, commonly containing granules to small pebbles. Conglomerate, is part matrix supported, occurs near the base of the sequence.

Although Ruetz (1979) apparently did not see the cliff exposure of the buttress unconformity, he interpreted the sequence north of Escondido as a submarine canyon deposit. Our observations of the buttress unconformity and the geometry of the overlying sandstone body clearly show that the sandstone was deposited in a relatively steep-walled northwest-trending channel cut in basement rocks. The width of the channel (about $1.5 \mathrm{~km})$ and the slopes $\left(14^{\circ}-23^{\circ}\right)$ are comparable to many of the ancient submarine canyons tabulated by Whitaker (1974). The sedimentary characteristics outlined above, together with Ruetz's (1979) description, show that the deposits are comparable to the sediments described from other submarine canyons (Mutti and Ricci Lucchi, 1975; Whitaker, 1974).

\section{REGIONAL STRATIGRAPHIC RELATIONS}

Previous workers (Graham, 1979a, b; Ruetz, 1979) have also reported submarine canyon deposits in the area. However, the stratigraphic correlation of these deposits was not clear and they were assigned different ages. Other workers (Link and Nilsen, 1979, 1980) may have correlated and included some midfan deposits with rocks that we consider canyon deposits, leading to a different interpretation of the sedimentary environment. We believe that the regional stratigraphic relations point to the presence of three northwest-trending submarine canyons filled with correlative strata.

At the type locality of the Reliz Canyon Formation in upper Reliz Canyon (Durham, 1963; fig. 1), the three members are well exposed (fig. 6C). The lower Junipero Sandstone Member is about $55 \mathrm{~m}$ thick, the medial Lucia Mudstone Member about 107 $m$ thick, and the upper The Rocks Sandstone Member about 442 $m$ thick (Durham, 1963). At some places in the northern Santa Lucia Range the Junipero Sandstone Member is absent. In places where the Lucia Mudstone Member is absent or too thin 

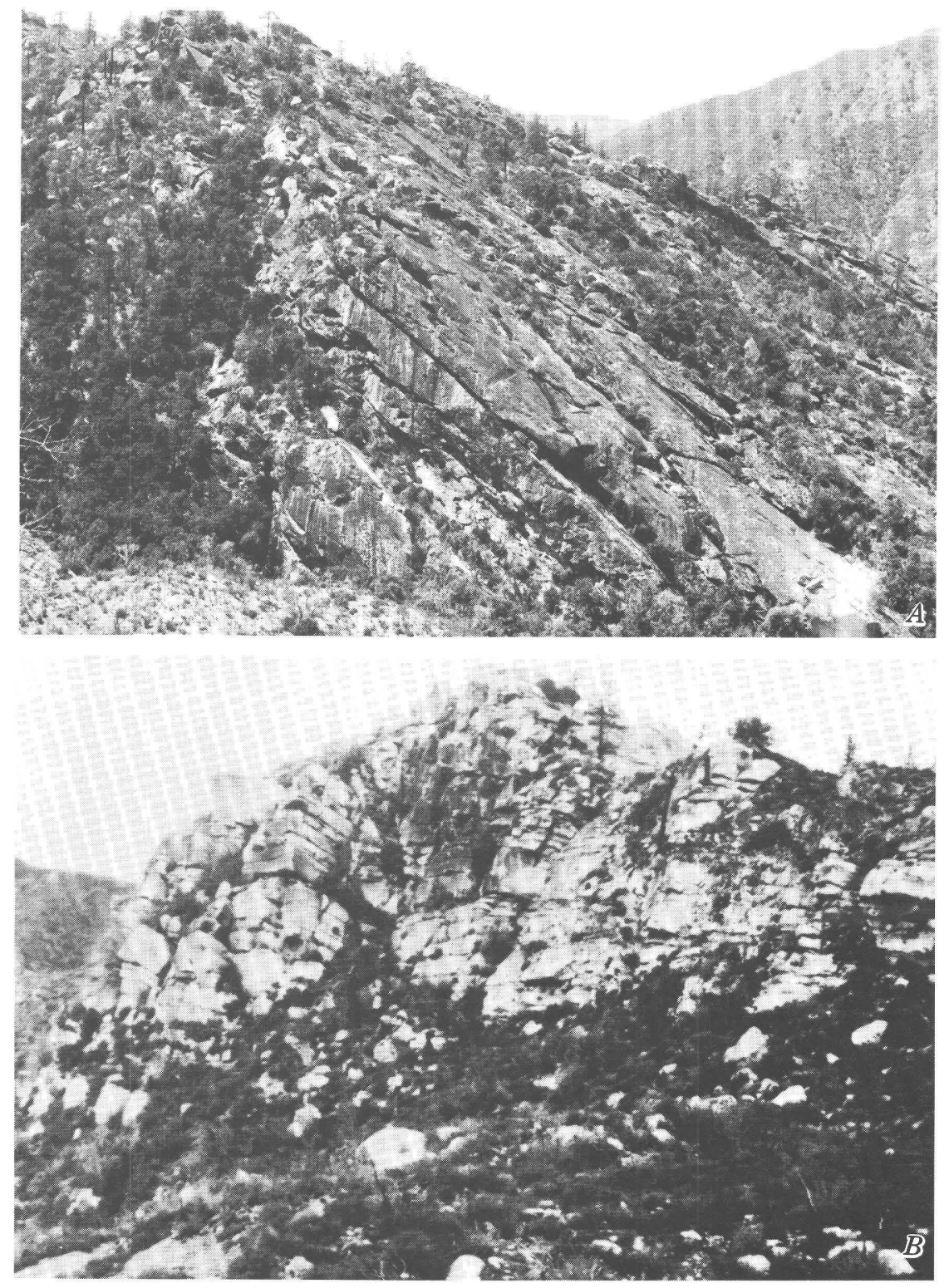

Figure 6.-Outcrops of the Reliz Canyon Formation. $A$, Dip slope in The Rocks Sandstone Member. View looking southwest from The Indians Road. Cliff exposure of buttress unconformity faces away from viewer, off photo to right. $B$, The Rocks Sandstone Member in section measured by Ruetz (1979), near fossil locality 2 (fig. 3). The Rocks Sandstone Member here is underlain by the Lucia Mudstone and Junipero Sandstone Members (out of view, below photograph). 

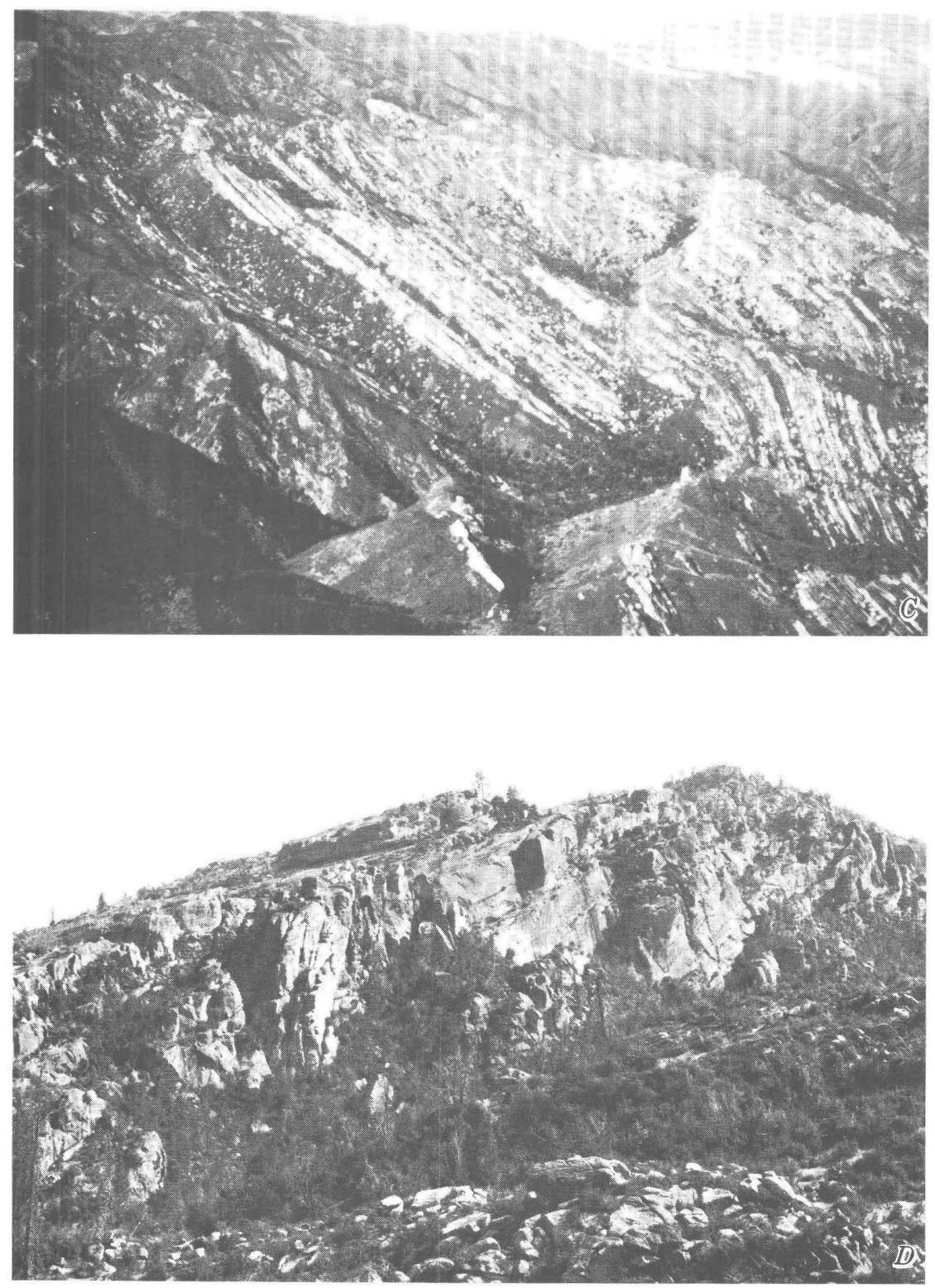

Figure 6.-Continued. $C$, The Reliz Canyon Formation $5 \mathrm{~km}$ northwest of the type locality. Thin, discontinuous sandstone unit at base of bedded sequence is the Junipero Sandstone Member. Steep brush-covered slopes to the right and stratigraphically above are underlain by the Lucia Mudstone. Large sandstone outcrops are The Rocks Sandstone Member (largely repeated by a fault in center of photograph). $D$, The Reliz Canyon Formation south of The Indians Ranger Station. 
to map, the Junipero and The Rocks Sandstone Members are not distinguished but are mapped together as the Reliz Canyon Formation, undivided. In most places The Rocks Sandstone Member is the thickest and best exposed member, typically forming cliffs and bold outcrops.

North of Escondido campground (figs. 1, 3), strata that we map as the Reliz Canyon Formation were assigned by Ruetz (1979) to an unnamed Paleocene formation, although no fossils had been found. Benthic foraminifers collected by us (table 1, fig. 3, localities 2-4), however, show that this unit is Eocene in age (K. A. McDougall, written commun., 1983). Moreover, the tripartite stratigraphy and the close lithologic similarities, especially the propensity to form prominent outcrops, also suggest correlation with the Reliz Canyon Formation.

In the same area, strata that overlie The Rocks Sandstone Member and are assigned by us to the Church Creek Formation, were mapped as The Rocks Sandstone by Link and Nilsen (1979, 1980). However, these beds consist of about 70 percent mudstone and siltstone with subordinate channelized sandstone bodies. Lithologically, they are better correlated with the Church Creek Formation. Poore and others (1977) suggested a late early Eocene age for foraminifers collected from these beds along The Indians road. They noted, however, that the faunas are poorly preserved and contain some species that range into the middle Eocene. Therefore, they did not exclude an early middle Eocene age. Indeed, planktic foraminifers found by us at locality 5 (table 1, fig. 3), near the base of the Church Creek Formation, include distinctive middle Eocene species, Truncorotaloides topliensis Cushman and Globorotalia bullbrooki Bolli, and the fauna is here assigned to the lower middle Eocene (Gerta Keller, written commun., 1983).

Deposits of another submarine canyon have been described by Graham (1979a, b) from the area just south of that discussed above. Graham (1979a) noted the lithologic similarity (fig. 6D) and possible correlation of these deposits with the Reliz Canyon Formation. However, he reported middle Eocene fossils from the deposits, and, because he considered the Reliz Canyon to be no younger than early Eocene, he provisionally assigned these rocks to the Church Creek Formation. Graham's (1979a) views on the age of the Reliz Canyon Formation may have been shaped by the tentative early Eocene age reported by Poore and others (1977) for the beds north of Escondido campground which we map as Church Creek. Since our data show that the base of the Church Creek is early middle rather than late early Eocene, 
TABLE 1.-Fossils from Paleocene and Eocene rocks north of Escondido campground

[Stratigraphic and fossil age assignments are as follows: 1, unnamed mudstone, tentatively late Thanetian (Paleocene); 2, Lucia Mudstone Member, Tertiary; 3 and 4, Lucia Mudstone Member, Eocene; 5, Church Creek Formation, early middle Eocene (Zones P10-P11); 6, Church Creek Formation, Eocene]

USGS NOF No-
MaP

Benthic foraminifers ${ }^{1}$

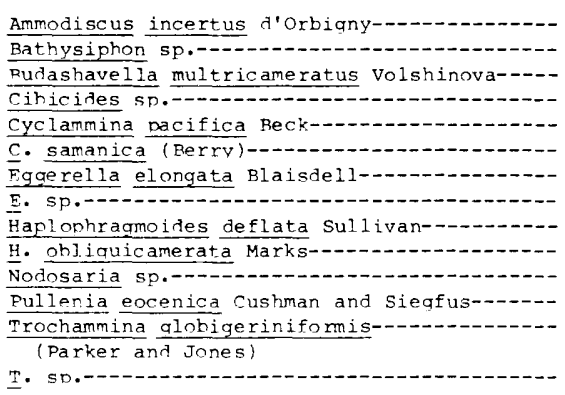

Planktic foraminifers ${ }^{2}$

Glohigerina lineaperta (Finlay)--
G. Drimativa (Finlay)
G. Senni (Reckmann)-

Megafossils ${ }^{3}$

\begin{tabular}{|c|c|c|c|c|c|c|}
\hline ?Campaniliopa n. sp.-- & $\mathrm{x}$ & - & - & - & - & - \\
\hline "Iromium" cf. "C.." andersoni- & $\mathrm{x}$ & - & - & - & - & - \\
\hline ?Cucul laea mathewsoni Gabb-- & $\mathrm{x}$ & - & - & - & - & - \\
\hline 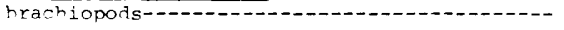 & $\mathrm{x}$ & - & - & - & - & - \\
\hline nautiloid- & $\mathrm{x}$ & - & - & - & - & - \\
\hline
\end{tabular}

\footnotetext{
IIdentified by Kristin A. McDougall

2 Identified hy Gerta Keller

${ }^{3}$ Identified by LouEl la Saul
}

the middle Eocene submarine canyon deposits of Graham(1979a) can be assigned to the Reliz Canyon without equivocation. The relation between the submarine canyon deposits of Graham $(1979 \mathrm{a}, \mathrm{b})$ and those north of Escondido campground is shown schematically in figure 7 , a paleogeographic block diagram. In addition to thick sandstone beds typical of the Reliz Canyon Formation (fig. $6 D$ ), the canyon deposits described by Graham 


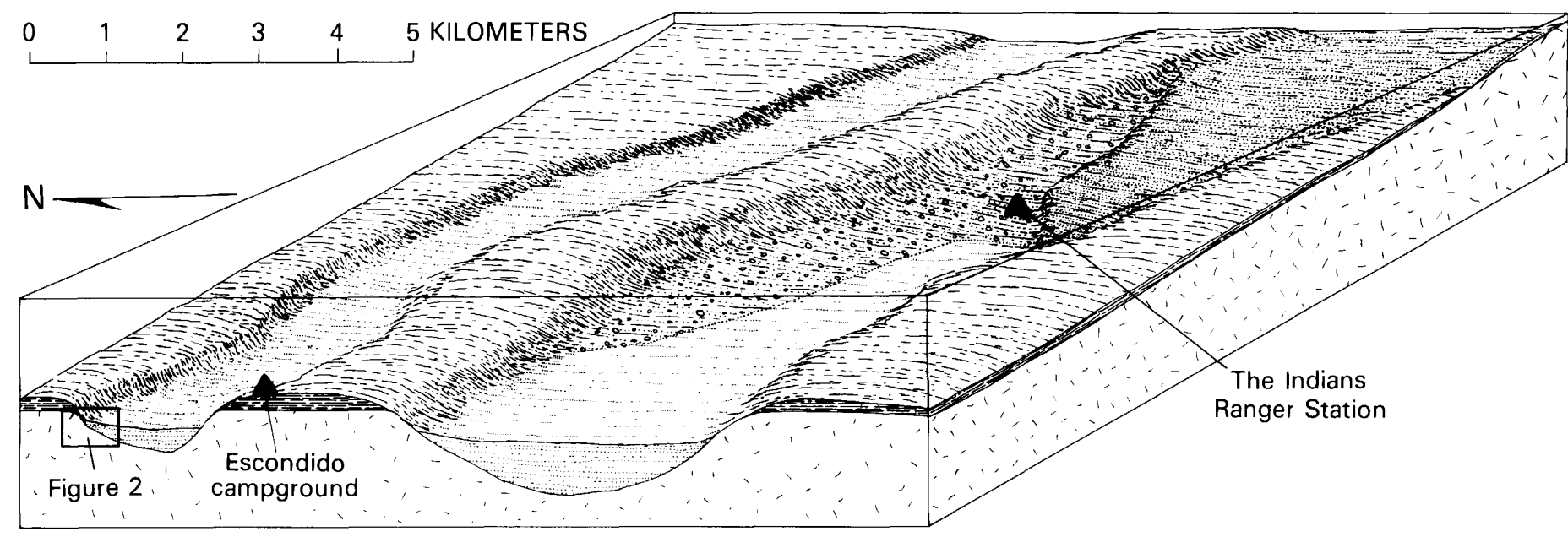

FIGURE 7.-Paleogeographic block diagram showing the inferred relation of the submarine canyon deposits exposed north of Escondido campground to the deposits described by Graham (1979a,b) near The Indians Ranger Station. 
(1979a, b) include coarse-grained conglomerate exposed north of The Indians Ranger Station (figs. 1, 7). According to Graham (1979a), this conglomerate may have been fed from shallow marine conglomeratic sandstone deposits exposed south and southeast of The Indians Ranger Station. Graham's canyon deposits are separated from those exposed north of Escondido campground by a submarine basement high. East of Escondido campground this basement high is overlain by a thin stratigraphic sequence, rich in mudstone, that contains late Paleocene and Eocene fossils (Graham, 1979a, b).

The buttress unconformity exposure north of Escondido campground clearly shows that, at least locally, a basement high separates those submarine canyon deposits from more extensive outcrops of the Reliz Canyon Formation to the north and east (fig. 1). These outcrops form a discontinuous belt extending from southeast of Reliz Canyon for $50 \mathrm{~km}$ to the northwest, everywhere less than 10 kilometers wide. The Rocks Sandstone Member in this belt was studied by Link and Nilsen $(1979,1980)$ who reported that the unit consists mainly of facies-B sandstone of Mutti and Ricci Lucchi (1975), with local facies-A sandstone and conglomerate. Paleocurrent directions are generally northwest, parallel to the belt, but turn northeast in the area northwest of Tassajara Hot Springs (fig. 1). Link and Nilsen $(1979,1980)$ interpreted The Rocks Sandstone as channelized middle-fan deposits but noted the absence of associated inner- and outer-fan facies. Interchannel deposits are also rare, especially when a mudstone-rich section (section B of Link and Nilsen, 1979, 1980) is relegated to the Church Creek Formation. Deposition may have been in a linear restricted basin, a possibility suggested by Link and Nilsen (1979, 1980), or a submarine canyon. The term deep-sea fan seems to be inappropriate for these deposits.

\section{AGE SIGNIFICANCE}

Fossils in the Reliz Canyon Formation, except in the Lucia Mudstone Member, are rare. Dickinson (1965) found Eocene, possibly Penutian, fossils in the Junipero Sandstone Member. Graham (1979a, b) reported late Paleocene fossils locally at the base of the formation and middle Eocene fossils higher in the section associated with conglomerate and sandstone. Kleinpell and others (1967) found Ulatisian fossils in The Rocks Sandstone Member. The richly fossiliferous Lucia Mudstone Member was most recently and precisely dated by Poore and 
others (1977). Benthic foraminifers are of Ulatisian age and planktic foraminifers are of late early Eocene age, referable to Zone P7-P8, and locally to Zone P9 at the top. The foraminiferal ages are partly supported by data from nannofossils (Sullivan, 1965; Bukry and others, 1977). An upper age limit for the Reliz Canyon Formation is given by our data from the lower part of the Church Creek Formation (locality 5, table 1, fig. 4) which indicate a middle Eocene age, Zones P10-P11. Thus, The Rocks Sandstone Member is bracketed by the late early Eocene Zone P9 and the early middle Eocene Zones P10-P11.

The fossil data indicate that the great volume of sand represented in The Rocks Sandstone Member was deposited rapidly at about the time of the early-middle Eocene boundary (placed at the Zone P9-P10 boundary by Berggren, 1972). This time interval correlates with a postulated worldwide low stand of sea level (Vail and others, 1977; Vail and Hardenbol, 1979). During low stands of sea level, deposition in deep-sea fans and basins is accelerated, apparently because the low sea level permits streams to transport coarse-grained detritus across the shelf directly to the heads of submarine canyons (Vail and others, 1977; Shanmugam and Moiola, 1982). The sand-rich deepsea deposits of The Rocks Sandstone Member have all the characteristics predicted by this hypothesis. Therefore, it is likely that deposition was at least partly influenced by a sealevel regression, although tectonism may have been a contributing factor.

\section{REFERENCES CITED}

Berggren, W. A., 1972, A Cenozoic time-scale-some implications for regional geology and paleobiogeography: Lethaia, v. 5, p. 195-215.

Bukry, David, Brabb, E. E., and Vedder, J. G., 1977, Correlation of Tertiary nannoplankton assemblages from the Coast and Peninsular Ranges of California: Segundo Congreso Latinoamericano de Geologia, Memoria, v. 3, p. 1461-1483.

Dickinson, W. R., 1965, Tertiary stratigraphy of the Church Creek area, Monterey County, California: California Division of Mines and Geology Special Report 86, p. 25-44.

Durham, D. L., 1963, Geology of the Reliz Canyon, Thompson Canyon, and San Lucas quadrangles, Monterey County, California: U.S. Geological Survey Bulletin 1141-Q, $41 \mathrm{p}$.

Enos, Paul, 1974, Reefs, platforms, and basins of middle Cretaceous in northeast Mexico: American Association of Petroleum Geologists Bulletin, v. 58, p. 800-809.

Graham, S. A., 1979a, Tertiary stratigraphy and depositional environments near Indians Ranch, Monterey County, California, in Graham, S. A., ed., 
Tertiary and Quaternary geology of the Salinas Valley and Santa Lucia Range, Monterey County, California: Society of Economic Paleontologists and Mineralogists, Pacific Section, Pacific Coast Paleogeography Field Guide 4, p. 3-12.

-1979b, Field trip roadlog, day 1: Stratigraphy and structure of Tertiary rocks, King City to Indians Ranch area, Los Padres National Forest, in Graham, S. A., ed., Tertiary and Quaternary geology of the Salinas Valley and Santa Lucia Range, Monterey County, California: Society of Economic Paleontologists and Mineralogists, Pacific Section, Pacific Coast Paleogeography Field Guide 4, p. 101-117.

Kleinpell, R. M., Weaver, D. W., and Doerner, D. P., 1967, Glimpses of the Paleogene depositional record west, north, northeast, and east of the Gabilan Mesa, in Guidebook, Gabilan Range and adjacent San Andreas fault: American Association of Petroleum Geologists and Society of Economic Paleontologists and Mineralogists, Pacific Sections, p. 38-44.

Link, M. H., and Nilsen, T. H., 1979, Sedimentology of The Rocks Sandstone and Eocene paleogeography of the northern Santa Lucia basin, California, in Graham, S. A., ed., Tertiary and Quaternary geology of the Salinas Valley and Santa Lucia Range, Monterey County, California: Society of Economic Paleontologists and Mineralogists, Pacific Section, Pacific Coast Paleogeography Field Guide 4, p. 25-43.

1980, The Rocks Sandstone, an Eocene sand-rich deep-sea fan deposit, northern Santa Lucia Range, California: Journal of Sedimentary Petrology, v. 50 , p. $583-602$.

Mutti, Emiliano, and Ricei Lucchi, Franco, 1975, Turbidite facies and facies associations, in Examples of turbidite facies and facies associations from selected formations of the northern Apennines: Ninth International Congress of Sedimentology, Nice, France, Field Trip Guidebook A-11, p. 21-36.

Poore, R. Z., Sliter, W. V., and Link, M. H., 1977, Lower Tertiary biostratigraphy of the northern Santa Lucia Range, California: U.S. Geological Survey Journal of Research, v. 5, no. 6, p. 735-745.

Ruetz, J. W., 1979, Paleocene submarine fan deposits of the Indians Ranch area, Monterey County, California, in Graham, S. A., ed., Tertiary and Quaternary geology of the Salinas Valley and Santa Lucia Range, Monterey County, California: Society of Economic Paleontologists and Mineralogists, Pacific Section, Pacific Coast Paleogeography Field Guide 4, p. 13-24.

Seiders, V. M., Esparza, L. E., Sabine, Charles, Spear, J. M., Stebbins, Scott, and Benham, J. R., 1983a, Mineral resource potential map of part of the Ventana Wilderness and the Black Butte, Bear Mountain, and Bear Canyon Roadless Areas, Monterey County, California: U.S. Geological Survey Miscellaneous Field Studies Map MF-1559-A, scale 1:50,000.

Seiders, V. M., Joyce, J. M., Leverett, K. A., and McLean, Hugh, 1983b, Geologic map of part of the Ventana Wilderness and the Black Butte, Bear Mountain, and Bear Canyon Roadless Areas, Monterey County, California: U.S. Geological Survey Miscellaneous Field Studies Map MF-1559-B, scale 1:50,000.

Shanmugam, G., and Moiola, R. J., 1982, Eustatic control of turbidites and winnowed turbidites: Geology, v. 10, p. 231-235.

Sullivan, F. R., 1965, Lower Tertiary nannoplankton from the California Coast Ranges-part 2, Eocene: University of California Publications, Department of Geological Sciences Bulletin, v. 53, p. 1-75.

Vail, P. R., and Hardenbol, Jan, 1979, Sea-level changes during the Tertiary: Oceanus, v. 22, p. 71-79. 
Vail, P. R., Mitchum, R. M., Jr., and Thompson, S., III, 1977, Seismic stratigraphy and global changes of sea level, Part 4: Global cycles of relative sea level, in Payton, C. E., ed., Seismic stratigraphy-applications to hydrocarbon exploration: American Association of Petroleum Geologists Memoir 26, p. 83-97.

Whitaker, J. H. McD., 1974, Ancient submarine canyons and fan valleys, in Dott, R. H., Jr., and Shaver, R. H., Modern and ancient geosynclinal sedimentation: Society of Economic Paleontologists and Mineralogists Special Publication 19 , p. $106-125$. 

